Tér és Társadalom 16. évf. 2002/4. 149-152. p.

\title{
BELUSZKY PÁL: A NAGYALFÖLD TÖRTÉNETI FÖLDRAJZA
}

(Dialóg Campus Kiadó, Budapest-Pécs, 2001, 274 o.)

TIMÁR JUDIT

Az „Alföldi út” kérdöjeleiröl az 1990-es évek elején, Békéscsabán rendezett konferencián Beluszky Pál - három évtizedes Alföld-kutatással s többek között az „Alföld-szindróma" eredetét boncolgató cikkével (1988) maga mögött - úgy látta:

„Ki később lépett az útra, ki le-letért róla, vagy elhagyta idejekorán. Nem is beszélhetünk valójában egyetlen útról; széles csapást képzelhetünk el, számos ösvénynyel. Minden település egyedi képzödmény, nem ritkán az egyes határrészek útja is merőben eltérö." $(1994,270)$

A települések egyediségére érzékeny, történész-szemlélettel megáldott geográfus mára több szakma számára izgalmas történeti földrajzi könyvvé érlelte az Alföld sajátos fejlödési pályájáról gyüjtött ismereteit.

Maga a téma - egy régió mint a kutatás fókusza - kézenfekvővé teszi, hogy párhuzamot vonjunk az anglo-amerikai történeti földrajz első korszakával, amikor a történeti geográfia és a regionális földrajz közös alapot talált a területi kapcsolatok és különbségek tanulmányozására. Aki azonban az ottani példa alapján az elmúlt idök földrajzi viszonyainak egyszerü rekonstruálását, az egyes történeti források aprólékos összetoldozásaként létrehozott keresztmetszetek felvázolását várja Beluszky Pál könyvétől is, téved. Ennél sokkal érdekesebb, gondolatébresztö oknyomozást követhet ugyanis végig: a szerzỏ egy napjainkban is aktuális kérdésre keresi a választ, az „alföldiség” kiváltó okainak, történeti gyökereinek a mibenlétét kutatja.

Többféle Alföld-térképet is számba véve Beluszky Pál kiindulásként lehatárolja az ,alföldi utat” járó területeket, majd szisztematikusan körbejárja a sajátosságuk magyarázatára eddig felmerült, illetve szóba jöhető okfejtéseket. A hazai geográfiára hosszú ideje jellemzö „zártsághoz” szokott olvasó számára különösen „üdító” és tanulságos a diszciplína határainál nem megtorpanó elemzés. A földrajzi és történeti megközelítéseken túl megismerkedhetünk néhány szociológus, néprajzos és „külhoni utazó" érveivel is. A szerző úgy mutatja be saját álláspontját, hogy valós lehetỏséget kínál az olvasónak is a választásra. Amíg például, ha el is ismeri, hogy a természeti viszonyok magyarázatot adnak a településállomány néhány jellegzetességére, maga úgy véli, hogy nem azok „terelték az 'alföldi útra' e nagytájunk társadalmi, gazdasági fejlödését". Mégis hosszasan foglalkozik Hamvas Bélának a táji adottságok és a lelki alkat, gazdálkodás, telepưléshálózat közti összefüggésekröl megfogalmazott elméletével. Ö azonban, ellentétben az elmúlt évtizedben Hamvast - magával ragadó stílusa, különleges gondolatai miatt - kritika nélkül idézö kutatókkal, több ellenérvet is felsorakoztat. E sorok írója csak azt sajnálja, hogy e kriti- 
kai gondolatsor „lezáratlanul”, a hamvasi tételekben megbúvó földrajzi determinizmus kimondatlanul maradt.

S hogy ne csupán ez az egyetlen példa álljon itt ízelítőül az inspiratív vitákból: Beluszky Pál felveszi a harcot azzal a meglehetősen elterjedt nézettel szemben is, mely az „elmaradottsággal” azonosítja, magyarázza az Alföld másságát. Ö okfejtésében azt igyekszik alátámasztani, hogy az „elmaradottság” sokkal inkább tekinthetô az Alföld-jelenség következményének, mint kiváltójának, s hogy nem is lehet $\mathrm{e}$ térséget ,idóbeli korlátok nélkül elmaradottnak ítélni”, mint tették azt oly sokan, pl. az itteni agrikultúrát értékelve kortársak és az utókor egyaránt:

„A véleményformálók többsége a Felvidékről vagy a Dunántúlról, esetleg Ausztriából származó államhivatalnok, gazdatiszt, adóösszeíró volt, nem ismerték fel a 'rendszert' az alföldi gazdálkodásban, így azt primitívnek minősítették. Számukra az agrártermelés sikerének fokméröje az egységnyi földterületröl nyert termék volt, mert a gazdálkodás 'szűk keresztmetszetét' az általuk példaadónak tartott tájakon a szükösen rendelkezésre álló földterület jelentette. $\mathrm{Az}$ alföldi gazdálkodás alapja ... egészen a 19. század elejéig jelentkező gabonakonjunktúráig a külterjes állattartás volt, ... földdel, legelővel bőséggel rendelkeztek, hiány - a rendelkezésre álló földterülethez képest - inkább a munkáskezekben mutatkozott. Ilyen feltételek mellett a rideg állattartás biztositotta az egységnyi ráfordított munkaeröre jutó legnagyobb hozadékot; a 19. századig ez a fajta gazdálkodás, $\mathrm{s}$ az ahhoz kapcsolódó agrotechnikai eljárások ... jelentették az okszerü, ésszerü gazdálkodást az Alföldön." (56. o.)

Ez az érvelés - úgy hiszem - szemléletével nyújt legtöbbet, késztet leginkább a továbbgondolásra. Mit is tekintünk általában ,példaadónak”, mennyire helyezzük középpontba a saját rendszereinket, amikor rásütjük valamire, jelen esetben egy térségre a ,másság” bélyegét? Lehet, hogy szerencsésebb lenne az Alföldet sem a „MÁSSÁGOK földjének” tekinteni, hanem inkább csak a sajátosságairól beszélni?

Mivel a szerző a természeti tájon kívül a „,nomád örökséget”, a megkésettséget, a periféria-, illetve frontier-jelleget is legfeljebb csak e sajátosságok bizonyos részére nézve tartja magyarázó erejünek, ezért a társadalomfejlödési útban, a ma különös aktualitással bíró európai történeti régiók kérdéskörében keresi - arról világos áttekintést adva -, s végül találja meg az „átfogó választ”. A 15. századtól kezdődő, a „,feudalizmus elötti” állapotból az azt meghaladó állapotba való jutás különös, jellegadó korszaka utáni török hódoltság alatt „kettős uralom alatt álló, mégis hatalmi ürrel jellemezhető tájon" kialakult mezővárosi lét lényegét bemutatva világossá teszi álláspontját: ,....az Alföld MÁSSÁGÁNAK forrása nem más, mint egy a környezeténél 'nyugatiasabb' társadalmi-gazdasági modell eltérése a közép-európai viszonyoktól." (73. o.)

Okfejtése közben olyan izgalmas kérdés felvetésére is módot talál Beluszky Pál, ami akár egy új kutatási iránynak is utat nyithatna, hiszen emlékeztet a korunkban nyugaton széles körben hódító kulturális geográfia lokalitást, területi differenciáltságot hangsúlyozó gondolatvilágára. A szerző ugyanis a „köztes terület”, a „kompország” gondolatától az „egy ország - több történeti régió” lehetőségéig 
eljutva azt a dilemmát fogalmazza meg, hogy vajon milyen területi léptékig mehetünk „le”, amikor ezekben a „makromodellekben” gondolkodunk. A feudális kor társadalmi viszonyai között ugyanis az Alföldön szinte mérföldröl mérföldre váltakoztak a „,szabad királyi városok, 'szabadalmas területek', földesúri mezővárosok, szabad menetelü parasztok $s$ röghöz kötött jobbágyok falvai”. Ez „mindmegannyi eltérö fejlődési modell lett volna?" (66. o.)

A kötet az alföldi út eredete után annak földrajzi következményeivel foglalkozik. A mezővárosok 15-17. századi, majd egy újabb nagy fejezetben a 18-19. századi bemutatása után két rövid epilógusban, még ha korszakonként nem is arányosan, de legfőbb csomópontjait tekintve végül is máig követhetjük az Alföld fejlödéstörténetének sajátosságait. Közben az az olvasói igény is beteljesülhet, amely a jogállásról, a gazdálkodásról, a határhasználatról, a városi funkciókról, illetve társadalomról, a vallásról, a szabadparaszti fejlődésről, az újrafeudalizációról, a települések „osztottságáról”, vagy a tanyás települési-gazdálkodási rendszerről kíván átfogó alföldi képet (leírást) kapni.

A szerző ráadásul - hủen a történeti földrajz müfajához - korántsem csak a közölt ábrák, térképek sokaságával, nem csak a településállomány típusok, illetve hierarchia-szintek szerinti elemzésével közvetít geográfiai ismereteket. A „szabadparaszti" állapot mibenlétéröl összegzést adva például a területi különbségekre figyelve rámutat, hogy általánosságban nem beszélhetünk az Alföldön a „szabadparaszti” fejlődési pályáról, hiszen annak feltételei nemcsak időnként, de helyenként, azaz városról-városra is változtak. A térbeli differenciáltság feltárásánál is messzebb mutat viszont például az a gondolatsor, amelyben a szerzỏ a honfoglalás kori téli szállások és az alföldi településrendszerre oly jellemző ólaskertes települési forma közötti folytonosságról, illetve genetikai összefüggésröl folyó vitában nem az egyértelmủ igenlök vagy az elutasítók táborához csatlakozik. Míg fel tud hozni példaként olyan kis tájat, ahol a kétbeltelkes forma valószínüsíthetỏen megszakítatlan „folytatásként” élt tovább, olyanra is utal, ahol csak a 16-17. században alakult ki. Így a geográfiai szemlélet új eredményeket hozhat a magyarázatok terén is: a szerzö nagyon is elképzelhetőnek tartja, hogy e településforma ,nem egyetlen töröl fakad".

A folyamatok sokoldalú értékelése persze nem csak a tér és az idő dimenziójában jellemzője a könyvnek. A szerzó az alföldi sajátosságok előnyeiben és hátrányaiban, rétegzett mezővárosi társadalomban, eltérő érdekekben gondolkodik, ennyiféle metszetet is festve a vizsgált sokszínủ világról. A sikeresség mai, települési léptékú kutatásaihoz is rendkívül tanulságos például az újrafeudalizáció és a mezővárosok nagyon is váltakozó eredményü küzdelmének bemutatása. Végigkövetve, hogy a 16-17. században kialakult ,alföldi úton” járó települések száma mennyire megcsappant a 18. század elejére, s a 18-19. század már mennyire nem tekinthetỏ egyértelmủ sikertörténetnek, az olvasó - különösen, ha alföldi kötődésủ is - nem véletlenül vezeti el gondolatait a máig, amikor Beluszky Pál jóvoltából megérti, milyen sajátos, „innovatív" választ jelentett a tanyás gazdálkodási-települési rendszer kialakítása az adott korszakban. 
Ez a könyv a korábban kétkedö, területfejlesztésben érdekelt szakemberek és politikusok számára is világossá teszi, miért olyan fontos eszköz a történeti földrajz által nyújtott tudásanyag a területi tervezésben. Több társadalomtudományi diszciplína képviselöi - az empirikus ismereteken túl - térszemléletet, a geográfia és a regionális tudomány múvelöi és tanulói pedig sokoldalú - s nem utolsósorban kritikai szellemü - társadalomtudományi gondolkodásmódot tanulhatnak Beluszky Pál könyvéböl.

\section{Irodalom}

Beluszky P. (1988) Az „Alföld-szindróma” eredete. - Tér és Társadalom. 4. 3-28. o.

Beluszky P. (1994) Alföldi út? Alföldi ösvények! - Timár J. (szerk.) Az „alföldi út” kérdöjelei. MTA RKK ATI Békéscsabai Osztály, Békéscsaba. 263-271. o. 